\title{
Umbilical cord blood hematological parameters reference interval for newborns from Addis Ababa, Ethiopia
}

\author{
Ammanuel Angelo ${ }^{1,2}$, Girma Derbie $^{3}$, Asrat Demtse $^{4}$ and Aster Tsegaye ${ }^{2^{*}}$
}

\begin{abstract}
Background: Several factors like altitude, age, sex, pregnancy, socioeconomic status, life style and race influence hematological reference interval (RIs), which are critical to support clinical decisions and to interpret laboratory data in research. Currently there are no well-established Rls for cord blood hematological parameters of newborns in Ethiopia. This study aims to generate RIs for umbilical cord blood hematological parameters of newborns from Addis Ababa, Ethiopia.

Method: A cross-sectional study was conducted from January 1 to March 31, 2019 on healthy, term newborns (37-42 weeks) with normal birth weight born to apparently healthy pregnant mothers who had met the eligibility criteria. From 139 newborns, 2-3ml cord blood was immediately collected from the clumped cord using EDTA tube. The samples were analyzed using Sysmex KX 21 hematology analyzer. Data was entered and the 2.5th and 97.5th percentiles (upper and lower reference limit) were determined using non parametric method by SPSS version 23. The non-parametric independent Mann-Whitney $U$ test (Wilcoxon rank-sum test) was used to compare the distribution of the parameters between genders, modes of deliveries and gestational age. $P$ value less than 0.05 was considered to declare statistical significance.
\end{abstract}

Result: The median values and $95 \%$ reference interval for umbilical cord blood hematological parameters of newborns were as follows: WBC $=12.4[6.6-19.4] \times 10^{9} / \mathrm{L}, \mathrm{RBC}=4.51[3.55-5.52] \times 10^{12} / \mathrm{L}, \mathrm{HGB}=15.8[12.4-19.7] \mathrm{g} / \mathrm{dL}, \mathrm{HCT}=45.9[37.9-$ 56.3]\%, MCV = 102.1[83.9-111.6] fL, MCH = 35.3 [29.4-39.1] pg, MCHC = 34.3 [32.3-37.4] \%, PLT = $236[146-438] \times 10^{9} / \mathrm{L}$, $\mathrm{LYM}=37.5$ [16.6-63.0] \%, MXD = 7.9[1.7-15.8] \%, NEU = 53.7[30.3-78.4] \%, RDW = 15.6[12.0-19.0]\%, PDW = 11.0[9.1-15.7]\% and MPV $=9.4[8.1-11.8] \mathrm{fl}$. The current study found no significant difference between genders, except RDW $(P=0.01)$, and gestational age group, but there was significant difference for $\operatorname{WBC}(p=0.007), \operatorname{RBC}(p=0.018)$ and Absolute NEU $(p=0.001)$ by delivery type where newborns delivered through caesarean section had lower values for these three parameters compared to those with spontaneous delivery.

Conclusions: hematological reference intervals in cord blood were established for the first time from healthy newborns of Addis Ababa and its surrounding. The values are applicable for newborns from this area. Larger study throughout the country is warranted.

Keywords: CBC, Reference interval, Umbilical Cord Blood, Neonates, Ethiopia

\footnotetext{
* Correspondence: aster.tsegaye@aau.edu.et; tsegayeaster@yahoo.com

${ }^{2}$ Department of Medical Laboratory Sciences, College of Health Sciences,

Addis Ababa University, Addis Ababa, Ethiopia

Full list of author information is available at the end of the article
}

(c) The Author(s). 2021 Open Access This article is licensed under a Creative Commons Attribution 4.0 International License, which permits use, sharing, adaptation, distribution and reproduction in any medium or format, as long as you give appropriate credit to the original author(s) and the source, provide a link to the Creative Commons licence, and indicate if changes were made. The images or other third party material in this article are included in the article's Creative Commons licence, unless indicated otherwise in a credit line to the material. If material is not included in the article's Creative Commons licence and your intended use is not permitted by statutory regulation or exceeds the permitted use, you will need to obtain permission directly from the copyright holder. To view a copy of this licence, visit http://creativecommons.org/licenses/by/4.0/. The Creative Commons Public Domain Dedication waiver (http://creativecommons.org/publicdomain/zero/1.0/) applies to the data made available in this article, unless otherwise stated in a credit line to the data. 


\section{Introduction}

Reference intervals (RIs) aid in the interpretation of laboratory data in patient management, clinical trials, and selection of eligible participants for vaccine trials [1]. These values are affected by several factors including age, sex, race, geographical location and dietary pattern [2]. A wealth of published studies demonstrated the age related changes in hematological parameters. Neonates exhibit profound quantitative as well as qualitative hematologic differences compared to older children and adults [3]. At birth, hematological parameters of term newborns are significantly higher than those of older children and adults $[4,5]$. Thus, it is inappropriate to use adult reference ranges for the assessment of pediatric blood $[6,7]$.

On the other hand, utilizing a reference interval obtained from somewhere else to a population of interest could potentially lead to inappropriate patient management and unnecessary use of resources [8, 9]. Cord blood hematological parameters reference intervals are vital in neonatal care and transplantation medicine [10, 11]. Cord blood is a blood collected from long and helical cord that connects the fetus with the mother for substances exchange [12]. Establishing normal neonatal reference interval has been difficult because of drawing blood from healthy neonates. Challenges of getting ethical approval for this vulnerable group and consent from the mothers also explain why limited RIs established from cord blood. Moreover, apart from the neonates other maternal factors are also needed to be considered [13-16].

According to different studies, maternal anemia had effect on cord blood hemoglobin and newborn weight [17-20], although it has been reported that routine hematological values of newborns are independent to that of maternal hematological values [21, 22]. A likely explanation given by those stating the dependency on maternal status is the high micronutrient intake inadequacy during pregnancy [23-25]. Maternal factors like smoking habit [26], heavily drinking alcohol [27], medical problems like diabetic mellitus, eclampsia, hypertension [28-30] and mode of delivery and frequency of pregnancy affect the hematological profile of neonates [31-33]. Delayed cord clamping and umbilical cord milking also affect hematological parameters $[34,35]$. Otherwise, cord blood collection is a safe way to collect sample compared to cannula and other vascular catheters which cause thrombophlebitis, infection, and extravasation [36]. Thus, in the current study we used cord blood collection method.

In spite of the fact that reference intervals can play an important role in guiding the assessment of hematological changes in neonatal care, there is no published reference interval for hematological parameters in cord blood of Ethiopians except some earlier efforts from Central Ethiopia [37] and recently from Northwest [38]. This study aimed at providing such intervals for cord blood samples from Addis Ababa.

\section{Materials and methods \\ Study design and setting}

A cross-sectional study was conducted from January 1 to March 31, 2019 in Addis Ababa, Ethiopia. Addis Ababa is the capital city of Ethiopia and seat for African Union, located at an elevation of about $2440 \mathrm{~m}$ (about $8000 \mathrm{ft}$ ) above sea level. Study participants were recruited from mothers coming to St Peter Specialized Hospital to get delivery service. The hospital is one of the five Federal Hospitals under the Ministry of Health which is located in the beautiful mountainous Entoto area. It used to be a Tuberculosis (TB) Specialized Hospital for many decades and expanded its service in recent years to provide comprehensive service to the needy residents including maternal and child care. The hospital performs about 3600 deliveries annually.

\section{Sample size determination and sampling Technique}

A total of 139 newborns delivered in St. Peter Specialized Hospital were included in this study using convenient non-probability sampling technique. As per the Clinical Laboratory Standard Institute (CLSI) guideline, about 120 samples per partition is required to determine the $95 \%$ reference interval [2]. Employing the a priori selection method, eligible volunteering mothers aged 18 to 45 years were recruited in the study. Mothers with the following conditions were excluded: those with medical conditions like infectious (e.g. Hepatitis B, HIV, Syphilis), chronic illness (e.g. Insulin-dependent diabetes mellitus), obstetric (e.g. less than six months from abortion, preeclampsia), psychological problems and social habits (e.g. smoking, heavily alcohol drinking). Comprehensive techniques including diagnostic tests (laboratory tests, ultrasound) and history from their hospital card extracted using structured format were used to exclude mothers with the listed conditions. On the other hand, mothers who had $\mathrm{Hgb}>=11.0 \mathrm{~g} / \mathrm{dL}$ [39] and interpregnancy interval of more than or exactly 18 months as per WHO recommendation [40] were included in the study. Whereas, posteriori selection method was used to include eligible newborns who were term (37-42 weeks), had 5th minute Apgar score of $>=7$ and birth weight within $2.5-4 \mathrm{Kg}$. Babies with respiratory distress, meconium staining, gross congenital anomalies, umbilical cord with true knot, and babies delivered by instrumental delivery were excluded. 


\section{Data Collection Procedure}

Prior to data collection, all the professionals who participated in data collection were oriented about the aim of the study, selection of participants, data confidentiality, safety precautions during collection, transportation, and storage of cord blood samples. Predesigned questionnaire was used to collect demographic information and a brief medical history from consenting eligible mothers. As delivery is stressful event, all mothers were asked for an informed signed consent and answer the questionnaire by the help of the attending midwives before entering the labor room. The umbilical cord was clamped in at least $1 \mathrm{~min}$ after birth and $2-3 \mathrm{ml}$ of cord blood was collected by midwives or operation room (OR) nurse using EDTA tube. The sample was well mixed (8-10x) and immediately transported to hematology laboratory for analysis.

\section{Screening Tests}

Hepatitis B surface antigen, HIV and syphilis antibody tests are routinely performed for pregnant women as part of their antennal care (ANC) follow up. Ultrasonography test was also used to rule out fetal gross congenital anomalies. These data were used to select eligible mothers.

\section{Hematological Analysis}

Complete blood count (CBC) namely white blood cell (WBC), Diff count (neutrophil count (NEU\#), lymphocyte count (LYM\#), mixed cells count (MXD\#), neutrophil percentages (NEU\%), lymphocyte percentages (LYM\%), mixed cells percentages (MXD\%)) red blood cells (RBC), hemoglobin (HGB), hematocrit (HCT), mean corpuscular volume (MCV), mean corpuscular hemoglobin $(\mathrm{MCH})$, mean corpuscular hemoglobin concentration $(\mathrm{MCHC})$, red cell distribution width (RDW), platelets (PLT), mean platelet volume (MPV) and platelet distribution width (PDW) were analyzed using Sysmex KX-21 N (Sysmex Corporation, Kobe, Japan) [41] automated hematology analyzer. The analyzer performs 18 parameters within one minute. It utilizes three detector blocks for WBC (DC detection method), HGB (Non-cyanide HGB method), RBC and PLT (DC Detection method)). Peripheral blood smears from cord blood samples were prepared and stained using Wright's stain for investigation of red blood cell morphology, white blood cell and platelets abnormalities.

\section{Quality Assurance}

Cord blood was collected by experienced midwives or OR nurses following the guideline for cord blood sample collection. In addition, orientation was given on proper collection and handling of $\mathrm{CB}$. Three level whole blood controls were used to ensure the quality of CBC using Sysmex KX-21 N. All procedures were performed following standard operating procedures (SOPs).

\section{Statistical Analysis}

Data from the questionnaires and laboratory results were coded and checked for completeness. Data were then entered and analyzed using IBM SPSS-version 23 statistical software for windows. Following the CLSI guide, 2.5th and 97.5th percentiles for hematological parameters were calculated for 139 newborns of both genders. The non-parametric Mann-Whitney $U$ test was used to compare the distribution of the parameters between genders, delivery modes (other than Instrument assisted delivery), and gestational age groups. Additionally descriptive statistics (minimum, maximum, mean, SD, median) were also determined. $P$ value less than 0.05 was sued to declare statistical significance.

\section{Results}

A total of 139 healthy full-term newborns consisting of $67(47.9 \%)$ males and 72(51.8\%) females were enrolled in the study. About $82.7 \%$ of the mothers were in the age group 18-30 years, $15.8 \%$ were from outside Addis Ababa (surrounding Weredas), 84.9\% were literate, $55.4 \%$ unemployed, and $47.5 \%(66 / 139)$ were having first time delivery (Table 1).

For all hematological parameters, there were no statistically significant difference by gestational age [37-39.1 versus 39.2-42 months] $(p>0.05)$. Independent MannWhitney U (Wilcoxon rank-sum) test between delivery modes shows significant difference $(p<0.05)$ of which newborns delivered through caesarean section $(\mathrm{C} / \mathrm{S})$ had lowered value for WBC (median with $95 \%$ RIs) = 11.1[6.6-19.4], $\quad \mathrm{RBC}=4.39[3.55-5.52], \quad$ and absolute $\mathrm{NEU}=6.0[2.7-12.8]$ compared to newborns delivered through spontaneous vaginal delivery (SVD) with values for $\mathrm{WBC}=12.9[6.6-19.4], \quad \mathrm{RBC}=4.55[3.55-5.52]$, and absolute NEU $=7.6[2.7-12.8](p<0.05)$ (Table 2).

Sex specific and combined 2.5th and 97.5th percentile for complete blood count parameters from umbilical cord blood is summarized in Table 3. Statistically significant differences by sex were not detected for any of the parameters except RDW-CV in which females showed lower median value $(p<0.05)$ than males. The combined median and $95 \%$ reference value of cord blood parameters as shown in Table 3 were for $\mathrm{WBC}=12.4 \times 10^{9} / \mathrm{L}$ [6.6-19.4], $\mathrm{RBC}=4.51 \times 10^{12} / \mathrm{L}[3.55-5.52], \mathrm{HGB}=15.8 \mathrm{~g} / \mathrm{dL}[12.4-$ 19.7], $\mathrm{HCT}=45.9 \%$ [37.9-56.3], $\mathrm{MCV}=102.1 \mathrm{fL} \quad$ [83.9111.6], $\mathrm{MCH}=35.3 p g$ [29.4-39.1], $\mathrm{MCHC}=34.3 \%$ [32.3$37.4], \mathrm{PLT}=236 \times 10^{9} / \mathrm{L}[146-438], \% \mathrm{LYM}=37.5 \%$ [16.663.0], $\% \mathrm{MXD}=7.9 \% \quad[1.7-15.8]$, and $\% \mathrm{NEU}=53.7 \%$ [30.3-78]. 
Table 1 Sociodemographic and clinical characteristics of study participants in Addis Ababa, Ethiopia, January 1 to March 30,2020 $(n=139)$

\begin{tabular}{|c|c|c|c|c|}
\hline \multicolumn{3}{|l|}{ Information } & Frequency & Percent \\
\hline \multirow[t]{2}{*}{ Age of Mother (Years) } & \multicolumn{2}{|l|}{$18-30$} & 115 & 82.7 \\
\hline & \multicolumn{2}{|l|}{$31-45$} & 24 & 17.3 \\
\hline \multirow[t]{2}{*}{ Residence } & \multicolumn{2}{|l|}{ Addis Ababa } & 117 & 84.2 \\
\hline & \multicolumn{2}{|l|}{ Outside Addis Ababa ${ }^{a}$} & 22 & 15.8 \\
\hline \multirow[t]{2}{*}{ Educational level } & \multicolumn{2}{|l|}{ Illiterate } & 21 & 15.1 \\
\hline & \multicolumn{2}{|l|}{ Literate } & 118 & 84.9 \\
\hline \multirow[t]{2}{*}{ Employment Status } & \multicolumn{2}{|l|}{ Employed } & 62 & 44.6 \\
\hline & \multicolumn{2}{|l|}{ Unemployed } & 77 & 55.4 \\
\hline \multirow[t]{2}{*}{ Marital Status } & \multicolumn{2}{|l|}{ Married } & 133 & 95.7 \\
\hline & \multicolumn{2}{|l|}{ Other } & 6 & 4.3 \\
\hline \multirow[t]{2}{*}{ Pregnancy History } & \multicolumn{2}{|l|}{ Yes } & 73 & 52.5 \\
\hline & \multicolumn{2}{|l|}{ No } & 66 & 47.5 \\
\hline \multirow[t]{2}{*}{ Pregnancy Interval $(n=73)^{a}$} & \multicolumn{2}{|l|}{ 1-1year \& 6months } & 6 & 8.2 \\
\hline & \multicolumn{2}{|l|}{$>=2$ years } & 67 & 91.8 \\
\hline \multirow[t]{4}{*}{ Delivery mode } & \multirow[t]{2}{*}{ Previously } & SVD & 56 & 76.7 \\
\hline & & CS & 17 & 23.3 \\
\hline & \multirow[t]{2}{*}{ Currently } & SVD & 93 & 66.9 \\
\hline & & CS & 46 & 33.1 \\
\hline \multirow[t]{2}{*}{ Sex of Baby } & \multicolumn{2}{|l|}{ Male } & 67 & 48.2 \\
\hline & \multicolumn{2}{|l|}{ Female } & 72 & 51.8 \\
\hline \multirow[t]{2}{*}{ Weight of Baby (kg) } & \multicolumn{2}{|l|}{$2.5-3.0$} & 74 & 53.2 \\
\hline & \multicolumn{2}{|l|}{$>3$} & 65 & 46.8 \\
\hline \multirow[t]{2}{*}{ Gestational age (weeks) } & \multicolumn{2}{|l|}{$37.0-39.0$} & 60 & 43.2 \\
\hline & \multicolumn{2}{|l|}{$39.1-42.0$} & 79 & 56.8 \\
\hline
\end{tabular}

athese are special Weredas around Addis Ababa (Administrative divisions)

The study also tried to compare the established cord blood RI with that provided by Sysmex for 0-24 h old newborns and other previous studies. Most studies present their findings as Mean \pm SD and hence the comparison was made accordingly as described in Table 4.

\section{Discussion}

This study aimed at providing reference intervals for selected hematological parameters from cord blood samples and compares the findings with company derived as well as other published reports [41-45]. Comparison of results according to sex, delivery modes and gestational age group were done. There was no statistically significant gender difference $(p>0.05)$ for all hematological parameters except RDW, which was a consistent finding with that of Greece [46]. The study from Greece, unlike the current study, has reported gender differences for WBC, NEU and PLT as well. Whereas, previous studies including from Korea [47], South India [48], Nepal [49], Saudi Arabia [44], Iran [50], Nigeria [43] and Sudan
[42], on the other hand, concluded that there are no statistically significant differences by gender at this early life. Though the literature cannot provide consistent observations regarding gender difference in cord blood hematological parameters, the mechanisms remain to be well elucidated.

The current study demonstrated lower and narrowed RIs mainly for WBC, RBC, HGB, HCT and absolute 3 part differential counts (\#NEU, \#LYM, \#MXD) parameters compared to reference value provided by Sysmex KX-21 hematology analyzer for newborns $(0-24$ h). Notably, the difference in the Neutrophils RI was remarkable $(2.7-12.9$ versus $6.0-$ $26.0 \times 10^{9} / \mathrm{L}$, current versus Sysmex RIs, respectively) [41]. The consistency with a study from north Ethiopia, which reported a lower neutrophil count RI of $2.96-13.54 \times 10^{9} / \mathrm{L}$ compared to the RI given by the company using the same machine Sysmex KX$21 \mathrm{~N}$ corroborated the notion that neutropenia is a common condition in Africans [51]. 
Table 2 Independent (2 Groups) Mann-Whitney U Test* of selected hematological parameters by gender, mode of delivery and gestational age

\begin{tabular}{|c|c|c|c|}
\hline Parameters & $P$ - value by sex & $P$-value by mode of delivery & $P$-value by gestational age \\
\hline$\overline{W B C}\left(\times 10^{9} / L\right)$ & 0.787 & 0.007 & 0.366 \\
\hline $\mathrm{RBC}\left(\times 10^{12} / \mathrm{L}\right)$ & 0.075 & 0.018 & 0.852 \\
\hline $\mathrm{HGB}(\mathrm{g} / \mathrm{dL})$ & 0.374 & 0.110 & 0.904 \\
\hline HCT (\%) & 0.861 & 0.193 & 0.707 \\
\hline$M C V(f L)$ & 0.171 & 0.117 & 0.990 \\
\hline $\mathrm{MCH}(\mathrm{Pg})$ & 0.139 & 0.094 & 0.832 \\
\hline$M C H C(g / L)$ & 0.386 & 0.519 & 0.540 \\
\hline RDW-CV(\%) & 0.01 & 0.318 & 0.197 \\
\hline $\mathrm{PLT}\left(\times 10^{9} / \mathrm{L}\right)$ & 0.369 & 0.291 & 0.855 \\
\hline LYM\% & 0.274 & 0.348 & 0.325 \\
\hline MXD\% & 0.807 & 0.666 & 0.915 \\
\hline NEU\% & 0.227 & 0.262 & 0.315 \\
\hline LYM\# & 0.188 & 0.420 & 0.781 \\
\hline MXD\# & 0.657 & 0.157 & 0.765 \\
\hline NEU\# & 0.684 & 0.001 & 0.264 \\
\hline PDW-CV(\%) & 0.199 & 0.296 & 0.188 \\
\hline MPV (fL) & 0.913 & 0.858 & 0.503 \\
\hline
\end{tabular}

*P values less than 0.05 determines significance Level

In the current study, RBC, HGB and HCT values were higher compared to Taiwan [33], Greece [46], Korea [47], South India [48], Pakistan [45], Nepal [49], Nigeria [43] and Sudan [42]. These might be due to the high altitude in Addis Ababa and mode of deliveries in which the majorly of participants in our study had spontaneous vaginal delivery [31-33]. Except the lower reference limit of HGB which is lower than the study from northern part of Ethiopia, the median and upper limit are consistent with a study from north Ethiopia [38], which is also a highland area (i.e., 12.4-19.7 (15.8 g/dL) current study vs. 13.32-19.64 (16.0 g/dL) from north Ethiopia).

MCV value in this study was surprisingly lower than most studies [33, 42-44, 46-50] including the study from north Ethiopia [38] and needs further investigation. RDW value in our finding, which is a marker of anisocytosis, was lower than Saudi Arabia [44], Iran [50] and Nigeria [43] but higher than that of Greece [46]. Nutritional variations could contribute to the observed differences [39].

In the current study, we found higher total WBC compared to studies from Taiwan [33], Greece [46], Korea [47], and Nepal [49]. This might be due to spontaneous vaginal delivery was the major mode of delivery in our country which affect the fetal hemogram [31-33]. However, the reference values from South India [48], Saudi Arabia [44], Pakistan [45], and Nigeria [43] are slightly higher than our finding. The current WBC finding was also lower compared to the limited published data from Ethiopia. The respective median and $95 \%$ reference intervals were $12.4(6.6-19.4) \times 10^{9} / \mathrm{L}$ in the current study versus $13.1(7.0-20.9) \times 10^{9} / \mathrm{L}$ [37] from central Ethiopia using Coulter T 540 and $12.8(7.64-22.16) \times 10^{9} / \mathrm{L}$ from north Ethiopia [38]. Of note, the value is much lower than the currently in use company derived RI which is $9.0-30.0 \times 10^{9} / \mathrm{L}$. Such inconsistencies underscore the need for locally established RIs for the target population.

The PLT value in the present study was higher than Taiwan [33], Korea [47], Nepal [49] and Nigeria [43]; however, it was lower than studies from South India [48], Pakistan [45], Saudi Arabia [44], Iran [50] and Sudan [42]. Compared to the study from Ethiopia, the PLT count was slightly higher (146.0-438.0 (236) x10 $/ \mathrm{L}$ vs. 132.74-413.4 (276) $\left.\times 10^{9} / \mathrm{L}\right)$. Though technical differences in specimen handling and analysis [52] and cord clumping time [35] among the different studies cannot be ruled out, the current study has strictly followed protocols to ensure quality.

Physiological, nutritional and ethnic differences could also contribute to variations among populations, although the earlier study from Ethiopia favors environmental factors as a main cause [37]. Birth is also stressful event accompanied with hormone regulated inflammatory action which increases cell mobilization 
Table 3 Reference Intervals for umbilical cord hematological parameters by Sex of Newborns from January 1 to March 31, 2019 G.C, Addis Ababa, Ethiopia $(n=139)$

\begin{tabular}{|c|c|c|c|c|c|c|c|c|}
\hline Parameter & Sex & $\mathrm{N}$ & Median & Min & Max & 2.5 & 97.5 & $P$-value \\
\hline \multirow[t]{3}{*}{$\overline{W B C}\left(\times 10^{9} / L\right)$} & $M$ & 67 & 12.6 & 6.5 & 19.6 & 6.6 & 19.3 & 0.787 \\
\hline & $F$ & 72 & 12.4 & 5.8 & 23.5 & 6.1 & 23.2 & \\
\hline & Combined & 139 & 12.4 & 5.80 & 23.5 & 6.6 & 19.4 & \\
\hline \multirow[t]{3}{*}{$\mathrm{RBC}\left(\times 10^{12} / \mathrm{L}\right)$} & M & 67 & 4.59 & 3.54 & 5.70 & 3.59 & 5.59 & 0.075 \\
\hline & $\mathrm{F}$ & 72 & 4.44 & 3.10 & 5.70 & 3.37 & 5.30 & \\
\hline & Combined & 139 & 4.51 & 3.10 & 5.70 & 3.55 & 5.52 & \\
\hline \multirow[t]{3}{*}{$\mathrm{HGB}(\mathrm{g} / \mathrm{dL})$} & M & 67 & 15.9 & 12.3 & 20.0 & 12.4 & 19.8 & 0.374 \\
\hline & $F$ & 72 & 15.7 & 10.8 & 20.6 & 11.1 & 18.8 & \\
\hline & Combined & 139 & 15.8 & 10.8 & 20.6 & 12.4 & 19.7 & \\
\hline \multirow[t]{3}{*}{ HCT (\%) } & M & 67 & 46.0 & 36.0 & 60.2 & 37.9 & 57.8 & 0.861 \\
\hline & $F$ & 72 & 45.45 & 36.4 & 61.8 & 37.3 & 56.3 & \\
\hline & Combined & 139 & 45.9 & 36.0 & 61.8 & 37.9 & 56.3 & \\
\hline \multirow[t]{3}{*}{$\mathrm{MCV}(\mathrm{fL})$} & M & 67 & 102.0 & 81.9 & 115.5 & 82.1 & 112.8 & 0.171 \\
\hline & $\mathrm{F}$ & 72 & 102.3 & 85.4 & 123.3 & 88.5 & 113.5 & \\
\hline & Combined & 139 & 102.1 & 81.9 & 123.3 & 83.9 & 111.6 & \\
\hline \multirow[t]{3}{*}{$\mathrm{MCH}(\mathrm{Pg})$} & M & 67 & 35.1 & 28.6 & 39.7 & 28.8 & 39.4 & 0.139 \\
\hline & $F$ & 72 & 35.3 & 27.8 & 41.1 & 31.6 & 38.7 & \\
\hline & Combined & 139 & 35.3 & 27.8 & 41.1 & 29.4 & 39.1 & \\
\hline \multirow[t]{3}{*}{ MCHC (g/L) } & M & 67 & 34.6 & 32.6 & 37.5 & 32.8 & 37.2 & 0.386 \\
\hline & $F$ & 72 & 34.3 & 30.0 & 37.9 & 31.0 & 37.7 & \\
\hline & Combined & 139 & 34.3 & 30.2 & 37.9 & 32.3 & 37.4 & \\
\hline \multirow[t]{3}{*}{ PLT (x10 $/ \mathrm{L})$} & M & 67 & 230.0 & 145.0 & 469.0 & 146.7 & 466.2 & 0.369 \\
\hline & $\mathrm{F}$ & 72 & 241.5 & 141.0 & 433.0 & 146.0 & 418.2 & \\
\hline & Combined & 139 & 236.0 & 141.0 & 469.0 & 146.0 & 438.0 & \\
\hline \multirow[t]{3}{*}{ \%LYM } & M & 67 & 36.6 & 4.8 & 71.2 & 10.8 & 64.6 & 0.274 \\
\hline & $\mathrm{F}$ & 72 & 37.8 & 14.7 & 76.0 & 19.4 & 66.4 & \\
\hline & Combined & 139 & 37.5 & 4.8 & 76.0 & 16.6 & 63.0 & \\
\hline \multirow[t]{3}{*}{$\% M X D$} & M & 67 & 8.3 & 1.5 & 17.8 & 1.7 & 15.8 & 0.807 \\
\hline & $\mathrm{F}$ & 72 & 7.85 & 0.0 & 17.3 & 0.00 & 16.6 & \\
\hline & Combined & 139 & 7.9 & 0.0 & 17.8 & 1.7 & 15.8 & \\
\hline \multirow[t]{3}{*}{$\% N E U$} & M & 67 & 54.7 & 22.5 & 88.4 & 26.9 & 84.1 & 0.227 \\
\hline & $\mathrm{F}$ & 72 & 53.4 & 18.6 & 82.3 & 29.7 & 75.4 & \\
\hline & Combined & 139 & 53.7 & 18.6 & 88.4 & 30.3 & 78.4 & \\
\hline \multirow[t]{3}{*}{ \#LYM } & M & 67 & 4.4 & 0.8 & 7.7 & 1.9 & 7.7 & 0.188 \\
\hline & $\mathrm{F}$ & 72 & 4.6 & 1.7 & 10.6 & 1.9 & 10.4 & \\
\hline & Combined & 139 & 4.5 & 0.8 & 10.6 & 1.9 & 8.3 & \\
\hline \multirow[t]{3}{*}{$\# M X D$} & M & 67 & 1.0 & 0.0 & 2.4 & 0.1 & 2.3 & 0.657 \\
\hline & $F$ & 72 & 1.0 & 0.0 & 2.5 & 0.0 & 2.4 & \\
\hline & Combined & 139 & 1.0 & 0.0 & 2.5 & 0.1 & 2.4 & \\
\hline \multirow[t]{3}{*}{ \#NEU } & M & 67 & 6.8 & 1.9 & 15.7 & 2.0 & 15.4 & 0.684 \\
\hline & $\mathrm{F}$ & 72 & 6.3 & 2.5 & 11.2 & 2.8 & 10.8 & \\
\hline & Combined & 139 & 6.6 & 1.9 & 15.7 & 2.7 & 12.9 & \\
\hline RDW-CV (\%) & M & 67 & 16.0 & 12.9 & 18.3 & 13.0 & 18.3 & 0.01 \\
\hline
\end{tabular}


Table 3 Reference Intervals for umbilical cord hematological parameters by Sex of Newborns from January 1 to March 31, 2019 G.C, Addis Ababa, Ethiopia $(n=139)$ (Continued)

\begin{tabular}{|c|c|c|c|c|c|c|c|c|}
\hline Parameter & Sex & $\mathrm{N}$ & Median & Min & Max & 2.5 & 97.5 & $P$-value \\
\hline & $F$ & 72 & 15.0 & 12.0 & 19.0 & 12.0 & 19.0 & \\
\hline & Combined & 139 & 15.6 & 12.0 & 19.0 & 12.0 & 19.0 & \\
\hline \multirow[t]{3}{*}{ PDW-CV (\%) } & M & 67 & 11.2 & 9.1 & 16.5 & 9.3 & 16.2 & 0.199 \\
\hline & $F$ & 72 & 10.8 & 8.6 & 15.8 & 8.6 & 14.8 & \\
\hline & Combined & 139 & 11.0 & 8.6 & 16.5 & 9.1 & 15.7 & \\
\hline \multirow[t]{3}{*}{$\operatorname{MPV}(f \mathrm{~L})$} & M & 67 & 9.4 & 7.0 & 11.3 & 7.4 & 11.2 & 0.913 \\
\hline & F & 72 & 9.35 & 8.0 & 12.5 & 8.1 & 12.3 & \\
\hline & Combined & 139 & 9.4 & 7.0 & 12.5 & 8.1 & 11.8 & \\
\hline
\end{tabular}

[53]; hence, differences in this event could cause differential movement of cells and perhaps partly contribute to differences seen among studies. The hematological reference intervals for Ethiopian cord blood, might play important role in neonatal care and transplantation medicine (stem cell transplantation from cord) to establish Umbilical Cord Blood Bank (UCBB). Cord blood hematological analysis as well as stem cell transplantation service is not part of the routine clinical care in the country. It is, thus, recommended that laboratories to incorporate cord blood analysis to their routine test lists and laboratory handbooks. In line of improving the neonatal clinical service and establishment of stem cell transplantation, implementation of such practices is not an option in this era of advancement in the clinical field.

\section{Conclusions}

Since this study is pioneer of its kind with regards to selected hematological reference intervals in cord blood from Addis Ababa, the values obtained from our study could provide reference intervals for some hematological parameters in healthy newborns (0-24rs) of Addis Ababa

Table 4 Mean \pm SD or Median Comparison with company derived values and other published reference values

\begin{tabular}{|c|c|c|c|c|c|c|c|c|}
\hline \multirow[t]{2}{*}{ Parameters } & \multicolumn{3}{|c|}{ RI current study } & \multirow{2}{*}{$\begin{array}{l}\text { Sysmex KX } 21 \text { [41] } \\
\text { RI }\end{array}$} & \multirow{2}{*}{$\begin{array}{l}\text { Sudan [42] } \\
\text { Mean } \pm \text { SD }\end{array}$} & \multirow{2}{*}{$\begin{array}{l}\text { Nigeria [43] } \\
\text { Mean } \pm \text { SD }\end{array}$} & \multirow{2}{*}{$\begin{array}{l}\text { Saudi Arabia [44] } \\
\text { Median }\end{array}$} & \multirow{2}{*}{$\begin{array}{l}\text { Pakistan [45] } \\
\text { Mean } \pm \text { SD }\end{array}$} \\
\hline & Median & Mean \pm SD & $95 \% \mathrm{RI}$ & & & & & \\
\hline$\overline{W B C}$ & 12.4 & $12.4 \pm 3.38$ & $6.6-19.4$ & $9.0-30.0$ & $12.3 \pm 4.17$ & $13.1 \pm 5.20$ & 16.1 & $13.7 \pm 4.00$ \\
\hline $\mathrm{RBC}$ & 4.51 & $4.51 \pm 4.49$ & $3.55-5.52$ & $4.1-6.7$ & $4.34 \pm 0.60$ & $4.05 \pm 0.55$ & 5.10 & - \\
\hline HGB & 15.8 & $15.8 \pm 1.64$ & $12.4-19.7$ & $15.0-24.0$ & $14.4 \pm 1.55$ & $13.9 \pm 1.50$ & 17.7 & $15.4 \pm 1.90$ \\
\hline $\mathrm{HCT}$ & 45.9 & $46.1 \pm 4.62$ & $37.9-56.3$ & $44-70$ & $44.1 \pm 5.14$ & $44.8 \pm 5.78$ & 53.2 & - \\
\hline MCV & 102.1 & $101.2 \pm 5.97$ & 83.9-111.6 & 102-115 & $105.5 \pm 5.14$ & $110.4 \pm 11.88$ & 106 & $103.4 \pm 4.60$ \\
\hline $\mathrm{MCH}$ & 35.3 & $35.1 \pm 1.97$ & $29.4-39.1$ & $33.0-39.0$ & $33.5 \pm 1.99$ & $32.6 \pm 4.13$ & 35.5 & $33.8 \pm 1.60$ \\
\hline $\mathrm{MCHC}$ & 34.3 & $34.5 \pm 1.17$ & $32.3-37.4$ & $32.0-36.0$ & $33.1 \pm 1.19$ & $29.8 \pm 1.64$ & 33.2 & - \\
\hline RDW-CV & 15.6 & $15.4 \pm 1.60$ & $12.0-19.0$ & $11.8-15.6$ & $19.8 \pm 4.26$ & - & - & $18.5 \pm 18$ \\
\hline PLT & 236 & $245.5 \pm 69.78$ & $146.0-438.0$ & $140-385$ & $261 \pm 83.16$ & $225.1 \pm 72.21$ & 234 & $285 \pm 62$ \\
\hline LYM\% & 37.5 & $38.2 \pm 10.96$ & $16.6-63.0$ & - & - & - & - & - \\
\hline MXD\% & 7.90 & $8.0 \pm 3.44$ & $1.7-15.8$ & - & - & - & - & - \\
\hline NEU\% & 53.7 & $53.9 \pm 10.84$ & $30.3-78.4$ & - & - & - & - & - \\
\hline \#NEU & 6.6 & $6.7 \pm 2.42$ & $2.7-12.9$ & $6.0-26.0$ & - & - & - & $7.7 \pm 3.00$ \\
\hline \#LYM & 4.5 & $4.7 \pm 1.93$ & $1.9-8.3$ & $2.3-10.8$ & - & - & - & $5.1 \pm 1.80$ \\
\hline \#MXD & 1.0 & $1.1 \pm 0.88$ & $0.1-2.4$ & $0.1-3.6$ & - & - & - & - \\
\hline PDW & 11.0 & $11.6 \pm 2.22$ & $9.1-15.7$ & - & - & - & - & - \\
\hline MPV & 9.4 & $9.5 \pm 0.90$ & $8.1-11.8$ & - & - & - & - & - \\
\hline
\end{tabular}

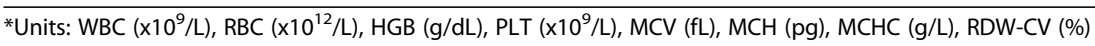


and its surrounding special weredas. However, the results need to be confirmed by larger samples from different parts of the country for wider use.

\begin{abstract}
Abbreviations
RI: Reference interval; EDTA: Ethylenediaminetetraacetic acid; CBC: Complete Blood Count; WBC: White Blood Cell; RBC: Red Blood Cell;

HGB: Hemoglobin; HCT: Hematocrit; MCV: Mean Cell Volume; MCH: Mean cell Hemoglobin; MCHC: Mean cell Hemoglobin Concentration; RDWCV: Red Cell Distribution Width-Coefficient of variation; PLT: Platelet; LYM: Lymphocyte; MXD: mixed population of Monocytes Eosinophils and Basophils; NEU: Neutrophils; PDW: Platelet Distribution Width; MPV: Mean Platelet Volume; CS: Cesarean section; SVD: Spontaneous Vaginal Delivery
\end{abstract}

\section{Acknowledgements}

The authors would like to acknowledge study participants for their kind collaboration, Addis Ababa University for the financial support, St Peter Hospital for the material support, Midwives, OR nurses and Medical Laboratory Technologists of St Peter hospital for the unreserved support, Mr. Abebe and his wife Mrs. Helen (Importer and Wholesaler) for their support by providing EDTA Test Tube and Wright's Stain.

\section{Authors' contributions}

A.A \& A.T identified the problem, designed the study, interpreted data and drafted the manuscript; G.D an OB-GY specialist screened and selected the pregnant mothers and supervised the Cord Blood collection; A.D, a neonatologist advised regarding the neonates selection; A.A performed the laboratory analysis, data entry and analysis. All authors critically reviewed the draft and approved the final manuscript.

\section{Funding}

Addis Ababa University financially supported this study. Material support was obtained from St Peter Specialized Hospital and friends of PI. The funding body has no role in the design of the study and collection, analysis, and interpretation of data and in writing the manuscript.

\section{Availability of data and materials}

All data generated or analyzed during this study are included in this published article. The dataset can be available from the corresponding author on reasonable request.

\section{Declarations}

\section{Authors' information}

A.A has a Masters in Clinical Laboratory Science with specialty in Hematology \& Immunohematology from Department of Medical Laboratory Sciences (DMLS) of Addis Ababa University. A.T, PhD, Associate Professor in Hematology \& Immunohematology Unit of DMLS, AAU; G.D is an MD OB-GY specialist at St Peter Hospital, A.D is an MD, Neonatologist in School of Medicine, AAU

\section{Ethics approval and consent to participate}

The study protocol was reviewed and ethically approved by the Research and Ethics Committees of the Department of Medical Laboratory Sciences, College of Health Sciences, Addis Ababa University and St. Peter Specialized Hospital Research Department. The mothers of neonates consented to participate after informing them about the aim of the study, voluntary participation, confidentiality of the information and their right to withdraw from the study anytime. All methods were performed in accordance with the relevant guidelines and regulations.

\section{Consent for publication}

Not applicable.

\section{Competing interests}

The authors declare that they have no competing interests.

\section{Author details}

'Department of Medical Laboratory, St Peter Specialized Hospital, Addis Ababa, Ethiopia. ${ }^{2}$ Department of Medical Laboratory Sciences, College of Health Sciences, Addis Ababa University, Addis Ababa, Ethiopia. ${ }^{3}$ Department of Obstetrics and Gynecology, St Peter Specialized Hospital, Addis Ababa, Ethiopia. ${ }^{4}$ Department of Pediatrics and Child Health, School of Medicine/ Tikur Anbessa Specialized Hospital, College of Health Sciences, Addis Ababa University, Addis Ababa, Ethiopia.

Received: 18 January 2021 Accepted: 17 May 2021

Published online: 11 June 2021

\section{References}

1. Zeh CE, Odhiambo CO, Mills LA. Laboratory Reference Intervals in Africa, Blood Cell - An Overview of Studies in Hematology, In Terry E. Moschandreou, Editors. IntechOpen 2012; DOI: 10.5772/48250. Available from: https://www.intechopen.com/books/blood-cell-an-overview-ofstudies-in-hematology/laboratory-reference-intervals-in-africa

2. NCCLS. How to Define and Determine Reference Intervals in the Clinical Laboratory; Approved Guideline-Second Edition. NCCLS document C28-A2 [ISBN 1-56238-406-6]. NCCLS, 940 West Valley Road, Suite 1400, Wayne, Pennsylvania 19087 - 1898, USA 2000.

3. Proytcheva MA. Issues in Neonatal Cellular Analysis. Am J Clin Pathol. 2009; 131(4): 560-573. doi: https://doi.org/10.1309/AJCPTHBJ4I4YGZQC.

4. Lanzkowsky P, Lipton JM, Fish JD. Hematological Reference Values. In: Lanzkowsky's Manual of Pediatric Hematology and Oncology, 6th end. London: Elsevier Inc; 2016. Appendix 1, 709-728.

5. Esan AJ. Hematological differences in newborn and aging: a review study. Hematol Transfus Int J. 2016;3(3):178-190. DOI: https://doi.org/10.15406/ htij.2016.03.00067

6. Glasser L, Sutton N, Schmeling M, Machan JT. A comprehensive study of umbilical cord blood cell developmental changes and reference ranges by gestation, gender and mode of delivery. J Perinatol. 2015;35:469-475. https://doi.org/10.1038/jp.2014.241

7. Tauseef $\mathrm{K}$, Ali N, Ahmed S, Zafar $\mathrm{H}$, Anwar J. Variation in reference values of hematological parameters between regional and international literature amongst the neonates. ISRA Med J. 2011; 3(1):320-324.

8. Berg J, Lane V. Pathology Harmony; a pragmatic and scientific approach to unfounded variation in the clinical laboratory. Ann Clin Biochem. 2011; 48: 195-197. doi: https://doi.org/10.1258/acb.2011.011078.

9. Geffre A, Friedrichs K, Harr K, Concordet D, Trumel C, Braun JP. Reference values: a review. Vet Clin Pathol. 2009; 38(3): 288-298.

10. Carroll PD, Christensen RD. New and underutilized uses of umbilical cord blood in neonatal care. Matern Health, Neonatol Perinatol. 2015; 1:16: https://doi.org/10.1186/s40748-015-0017-2

11. Roura S, Pujal JM, Gálvez-Montón C and Bayes-Genis A. The role and potential of umbilical cord blood in an era of new therapies. Stem Cell Res Ther. 2015;6(1):123. doi: https://doi.org/10.1186/s13287-015-0113-2.

12. Spurway J, Logan P, Pak S. The development, structure and blood flow within the umbilical cord with particular reference to the venous system. Australas J Ultrasound Med. 2012; 15(3):97-102.doi: https://doi.org/10.1002/ j.2205-0140.2012.tb00013.x

13. Henry E, Chritensen RD. Reference Intervals in Neonatal Hematology. Clin Perinatol. 2015;42(3):483-97. doi: https://doi.org/10.1016/j.clp.2015.04.005.

14. Sikaris KA. Physiology and its Importance for Reference Intervals. Clin Biochem Rev. 2014; 35 (1):3-14.

15. Samantaray R, Pradhan BB. Effect of Faeto-Maternal Factors on Haematological Parameters of Cord Blood. IOSR J Dent Med Sci. 2015; 14(5): 92-96.

16. Qaiser DH, Sandila MP, Kazmi T, Ahmed ST. Influence of Maternal Factors on Hematological Parameters of Healthy Newborns of Karachi. Pak J Physiol 2009; 5(2):34-37.

17. Debbarma R, Debbarma B. Effect of Maternal Anaemia on Cord Haemoglobin and Birth Weight of Newborns. IOSR J Dent Med Sci. 2015; 14(7):19-21.

18. Dalal E, Shah J. A Comparative Study on Outcome of Neonates Born To Anemic Mothers versus Non Anemic Mothers. Natl J Med Res. 2014; 4(4): 270-273.

19. Rajendran R, Suman FR, Sudheer Raj RS, Kanna PR, Borra NR. Umbilical Cord Blood Hemogram: What Is the Effect of Maternal Anemia? Blood 2015; 126(3):4536.https://doi.org/10.1182/blood.V126.23.4536.4536

20. Dane B, Arslan N, Batmaz G, Dane C. Does maternal anemia affect the newborn? Turk Arch Ped. 2013; 48:195-199.

21. Qaiser DH, Sandila MP, Omair A, Ghori GM. Correlation of Routine Haematological Parameters Between Normal Maternal Blood and the Cord 
Blood of Healthy Newborns in Selected Hospitals of Karachi. College of Physicians and Surgeons Pakistan. 2013; 23 (2):128-131.

22. Timilsina S, Karki S, Gautam A, Bhusal P, Paudel G, Sharma D. Correlation between maternal and umbilical cord blood in pregnant women of Pokhara Valley: a cross sectional study. BMC Pregnancy and Childbirth. 2018; 18:70. https://doi.org/10.1186/s12884-018-1697-1

23. Sharma JB, Shankar M. Anemia in Pregnancy. JIMSA. 2010; 23(4):253-260

24. Adediran A, Gbadegesin A, Adeyemo TA, Akinbami A, Osunkalu V, Ogbenna A et al. Cord blood hemoglobin and ferritin concentrations in newborns of anemic and non-anemic mothers in Lagos, Nigeria. Niger Med J. 2013; 54(1):22-26.

25. Terefe B, Birhanu A, Nigussie P, Tsegaye A. Effect of Maternal Iron Deficiency Anemia on the Iron Store of Newborns in Ethiopia. Anemia 2015; 2015: https://doi.org/10.1155/2015/808204.

26. Kataoka MC, Carvalheira APP, Ferrari AP, Malta MB, de Barros Leite Carvalhaes MA, de Lima Parada CMG. Smoking during pregnancy and harm reduction in birth weight: a cross-sectional study. BMC Pregnancy Childbirth 2018; 18(1):67. doi: https://doi.org/10.1186/s12884-018-1694-4.

27. Nykjaer C, Alwan NA, Greenwood DC, Simpson NAB, Hay AWM, White KLM et al. Maternal alcohol intake prior to and during pregnancy and risk of adverse birth outcomes: evidence from a British cohort. J Epidemiol Community Health 2014; 68(6):542-549. doi: https://doi.org/10.1136/jech-2 013-202934

28. Cloherty JP, Eichenwald EC, Hansen AR, Stark AR. Manual of Neonatal Care. Philadelphia: Lippincott Williams \& Wilkins; 2012.

29. Mahran A, Fares H, Elkhateeb R, Ibrahim M, Bahaa H, Sanad A et al. Risk factors and outcome of patients with eclampsia at a tertiary hospital in Egypt. BMC Pregnancy Childbirth 2017; 17:435. doi: https://doi.org/10.1186/ s12884-017-1619-7.

30. Rawlins B, Plotkin M, Rakotovao JP, Getachew A, Vaz M, Ricca J et al. Screening and management of preeclampsia and eclampsia in antenatal and labor and delivery services: findings from cross-sectional observation studies in six sub-Saharan African countries. BMC Pregnancy Childbirth. 2018; 346. https://doi.org/10.1186/s12884-018-1972-1.

31. El Gendy FM, Allam AA, Allam MM, Allam RK. Haematological parameters of newborns delivered vaginally versus caesarean section. Menoufia Med J. 2016; 29(2):259-264. DOl: https://doi.org/10.4103/1110-2098.192429.

32. Younis MS, Elgari MM, Mohamed B, Idris EE. Effect of delivery mode on newborns cord blood hematological parameters. Cukurova Med J. 2017; 42(4):735-740.

33. Chang YH, Yang SH, Wang TF, Lin TY, Yang KL Chen SH. Complete Blood Count Reference Values of Cord Blood in Taiwan and the Influence of Gender and Delivery Route on Them. J Pediatr Neonatol. 2011; 52(3):155-160.

34. Jaiswal P, Upadhyay A, Gothwal S, Singh D, Dubey K, Garg A et al. Comparison of Umbilical Cord Milking and Delayed Cord Clamping in Term Neonates: A Randomized Controlled Trial. Acad J Pediatr Neonatol. 2015; 1(1):1-7.

35. Oliveira FdeC, Assis KF, Martins MC, do Prado MRMC, Ribeiro AQ, SantAna LFdaR et al. Timing of clamping and factors associated with iron stores in full-term newborns. Rev Saúde Pública 2014; 48(1):10-18.

36. Ramasethu J. Complications of Vascular Catheters in the Neonatal Intensive Care Unit. Clin Perinatol 2008; 35:199-222.

37. Tsegaye A, Wolday D, Otto S, Petros B, Assefa T, Alebachew T, et al. Immunophenotyping of blood lymphocytes at birth, during childhood, and during adulthood in HIV-1-uninfected Ethiopians. Clin Immunol. 2003;109(3): 338-46. doi: https://doi.org/10.1016/j.clim.2003.08.008.

38. Tiruneh T, Kiros T, Getu S. Hematological reference intervals among fullterm newborns in Ethiopia: a cross-sectional study. BMC Pediatr 2020;20:417. https://doi.org/10.1186/s12887-020-02320-5

39. WHO. Hemoglobin concentration for the diagnosis of anemia and assessment of severity. Vitamin and Mineral Nutrition Information System. Geneva, World Health Organization, 2011(WHO/NMH/NHD/MNM/11.1)http://www.who.int/ vmnis/indicators/haemoglobin.pdf, [accessed Nov 2018].

40. WHO. Report of a WHO Technical Consultation on Birth Spacing. Geneva, Switzerland 13-15 June 2005; 1-45. www.who.org.

41. Sysmex Corporation. Operator's Manual: Kx-21 Automated Hematology Analyzer. Kobe, Japan 2000; 1-306.

42. Elgari MM, and Waggiallah HA. Cord Blood Hematological Profile of Sudanese Neonates at Birth in Khartoum State. NJIRM. 2014; 5(4):22-25.

43. Adewumi A, Titilope AA, Akinsegun AA, Abidoye G, Ebele U, Sulaimon AA Cord blood full blood count parameters in Lagos, Nigeria. Pan African
Medical Journal. 2014; 17:192.doi: https://doi.org/10.11604/pamj.2014.17.1 92.3680. eCollection 2014.

44. Alharbi S, Alkhotani A. Hematological Reference Values for Full-Term, Healthy Newborns of Jeddah, Saudi Arabia. J Clin Neonatol. 2017; 6(1):19-22.

45. Pasha W, Ali W, Ahmed N, Khattak AL, Idris M, Nayyer ZA. Reference Hematological Values For Full Term Healthy Newborns From Rural Sindh, Pakistan. J Ayub Med Coll Abbottabad 2015; 27(2):375-377.

46. Katsares V, Paparidis Z, Nikolaidou E, Karvounidou I, Ardelean KA, Drossas N et al. Reference Ranges for Umbilical Cord Blood Hematological Values. Lab med. 2009; 40(7): 437-439.

47. Lee HR, Shin S, Yoon JH, Kim BJ, Hwang KR, Kim JJ et al Complete Blood Count Reference Values of Donated Cord Blood from Korean Neonates. Korean J Lab Med. 2009; 29(3):179-184.

48. Suman FR, Raj RSS, Priyathersini N, Rajendran R, Rajendran R, Ramadoss U. Biological Reference Interval for Hematological Profile of Umbilical Cord Blood: A Study Conducted at A Tertiary Care Centre in South India. J Clin Diag Research. 2015; 9(10): SC07-SC9. doi: https://doi.org/10.7860/JCDR/201 5/14713.6675

49. Basnet S, Singh SK, Sathian B, Mishra R. Reference Range for Hematological Values in Umbilical Cord Blood in Pokhara, Nepal. J Nepal Paediatr Soc. 2016; 36(2):160-164.

50. Keramati MR, Mohammadzadeh A, Farhat AS, Sadeghi R. Determination of Hematologic Reference Values of Neonates in Mashhad - Iran. Int J Hematol Oncol. 2011; 21(2):101-105.

51. Hsieh M, Chin K, Link B, Stroncek D, Wang E, Everhart J et al. Benign Ethnic Neutropenia in Individuals of African Descent: Incidence, Granulocyte Mobilization, and Gene Expression Profiling. Blood. 2005; 106:11. DOl:https:// doi.org/10.1182/BLOOD.V106.11.3069.3069.

52. Freise KJ, Schmidt RL, Gingerich EL, Veng-Pedersen P, Widness JA. The effect of anticoagulant, storage temperature and dilution on cord blood hematology parameters over time. Int J Lab Hematol. 2009; 31:496-504.

53. Mendelson CR. Fetal-Maternal Hormonal Signaling in Pregnancy and Labor. Mol Endocrinol. 2009; 23(7):947-954.

\section{Publisher's Note}

Springer Nature remains neutral with regard to jurisdictional claims in published maps and institutional affiliations.

Ready to submit your research? Choose BMC and benefit from:

- fast, convenient online submission

- thorough peer review by experienced researchers in your field

- rapid publication on acceptance

- support for research data, including large and complex data types

- gold Open Access which fosters wider collaboration and increased citations

- maximum visibility for your research: over $100 \mathrm{M}$ website views per year

At BMC, research is always in progress.

Learn more biomedcentral.com/submissions 